TITLE:

\title{
Reduction of Atlantoaxial Subluxation Causes Airway Stenosis(Abstract_要旨)
}

\author{
$\operatorname{AUTHOR}(\mathrm{S})$ : \\ Izeki, Masanori
}

CITATION:

Izeki, Masanori. Reduction of Atlantoaxial Subluxation Causes Airway Stenosis. 京都大学, 2014, 博士(医学)

ISSUE DATE:

2014-01-23

URL:

http://hdl.handle.net/2433/185188

RIGHT: 


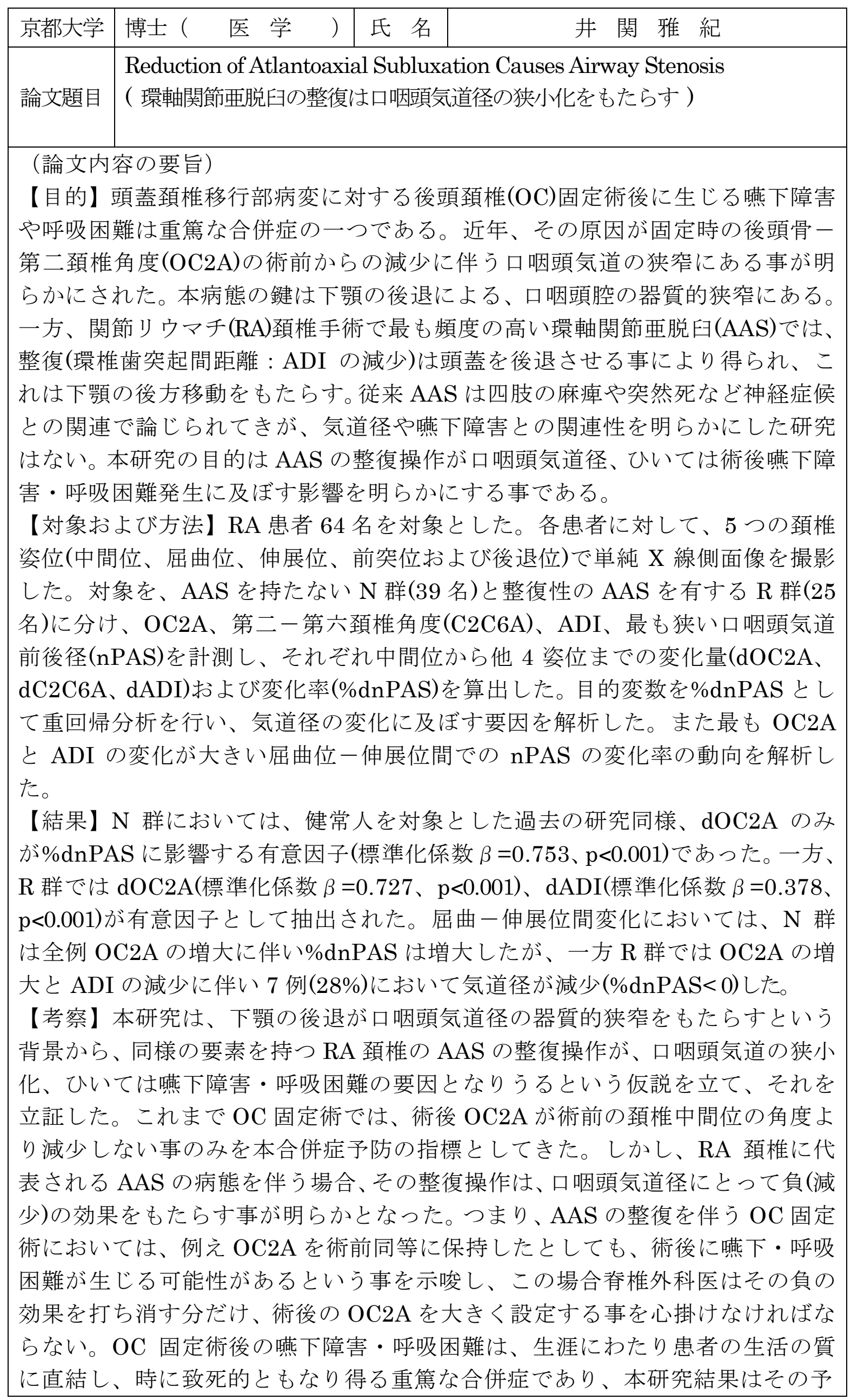

防と対策に大きく寄与する。また、 $\mathrm{RA}$ 患者に多いとされる閉塞性睡眠時無呼吸 症候群など上気道病変の病態解明や診断、治療においても有益な情報となりう る。今後 $\mathrm{AAS}$ の整復を伴う OC 固定術において、術後口咽頭気道径に影響する OC2A と ADI の変化を同時評価可能な、簡便で信頼性の高い、新たな指標の検 討が必要である。

(論文審査の結果の要旨)

本研究は、関節リウマチ $(\mathrm{RA})$ 頚椎病変の環軸関節覀脱臼(AAS)の整復（環椎歯突起間距 離 : ADI の減少）が、口咽頭気道径に及ぼす影響を調査した。後頭骨頚椎(OC)固定術後 の鱟下障害・呼吸困難の発生原因として、術前中間位に比べ固定時の後頭骨-第二頚椎角度 (OC2A)が減少し、下顎が後退することにより口咽頭気道の器質的狭窄をもたらす事が知 られている。AAS の整復でも同様に下顎が後退する。本研究では、AAS を有する患者の 頚椎姿位変化に伴う口咽頭気道径の変化率の検討から、OC2A の変化量に加え $\mathrm{ADI}$ の変 化量も影響を及ぼす事が明らかになった。これまで OC 固定術では、術後の OC2A を術 前䅡椎中間位の角度より減少させない事のみを、術後嬹下障害・呼吸困難の予防の術中指 標としてきた。しかし本研究結果は、AAS の整復は口咽頭気道径に負(狭小化)の効果をも たら寸為、 AAS の整復を伴う OC 固定手術においては、たとえ OC2A を術前中間位と同 等に保持したとしても、術後に嚥下障害・呼吸困難が生じる可能性があるという事を示唆 した。これは、春椎外科医に $\mathrm{AAS}$ 整復の効果を打ち消す分だけ、固定 $\mathrm{OC} 2 \mathrm{~A}$ を術前中間 位より大きく設定する必要性を啓発するものである。

以上の研究は、AAS の整復を伴う RA 後頭顏椎固定術後の燕下障害・呼吸困難の病態解明 に貢献し、その予防と対策また術後患者 QOL 向上に寄与ものである。

したがって、本論文は博士（医学）の学位論文として価值あるものと認める。

なお、本学位授与申請者は、平成 25 年 11 月 11 日実施の論文内容とそ れに関連した研究分野並びに学識確認のための試問を受け、合格と認められたものであ る。 